Foreshadowing a problem: Turn-opening frowns in conversation

\title{
Kaukomaa, Timo
}

2014-09

Kaukomaa , T , Peräkylä , A \& Ruusuvuori , J E 2014 , ' Foreshadowing a problem:

Turn-opening frowns in conversation ' , Journal of Pragmatics , vol. 71 , pp. 132-147 . https://doi.org/10.1016/j.pragm

http://hdl.handle.net/10138/156624

https://doi.org/10.1016/j.pragma.2014.08.002

unspecified

acceptedVersion

Downloaded from Helda, University of Helsinki institutional repository.

This is an electronic reprint of the original article.

This reprint may differ from the original in pagination and typographic detail.

Please cite the original version. 


\title{
Foreshadowing a problem: Turn-opening frowns in conversation
}

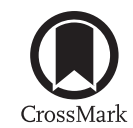

\author{
Timo Kaukomaa ${ }^{a,{ }^{*}}$, Anssi Peräkylä ${ }^{\mathrm{b}}$, Johanna Ruusuvuori ${ }^{\mathrm{c}}$ \\ ${ }^{a}$ Department of Social Research/Sociology, P.O. Box 4 (Vuorikatu 4), 00014 University of Helsinki, Finland \\ ${ }^{\mathrm{b}}$ Department of Social Research/Sociology, P.O. Box 18, 00014 University of Helsinki, Finland \\ c School of Social Sciences and Humanities/Social Psychology, 33014 University of Tampere, Finland \\ Received 5 September 2013; received in revised form 4 June 2014; accepted 2 August 2014
}

\begin{abstract}
Occasionally in conversation, a participant starts to frown during a silence between utterances, before starting to talk. The purpose of our study was to determine how these frowns contribute both to the upcoming turn and to the larger conversational context. The results suggest that these frowns mark the following utterance as dealing with something problematic in relation to the expectations created in the preceding talk. As pre-beginning elements, these frowns anticipate utterances that involve difficulties associated with negative evaluation, disaffiliation, or epistemic challenge. All three types of problem involve some complication that arises in the expected course of events within the interaction. These frowns seem to foreshadow utterances that somehow deviate from the recipient's routine expectation. As these frowns persist into the utterances they anticipate, they become intertwined with what is being said. Furthermore, the utterance or utterances that follow(s) the turn-opening frown expose(s) the grounds for that problem. Turn-opening frowns are typically produced by the frowning participant gazing downward and away from the recipient. The recipients of these frowns do not typically reciprocate them even though they notice the frown. However, these facial expressions work as an important interactional resource for the interlocutors, hinting beforehand at a problem in the conversation that will be addressed in the upcoming turn of talk.
\end{abstract}

(C) 2014 Elsevier B.V. All rights reserved.

Keywords: Facial expression; Frown; Problem; Turn construction; Dispreference; Conversation analysis

\section{Introduction}

During conversation, participants sometimes frown just before the onset of their spoken utterances and the frown remains on their faces when they start to talk. As the talk and interaction unfold, it becomes clear that this type of frown is connected to the utterance. Our data show that the turn-opening frown indicates that something problematic is about to arise in the upcoming turn. What it is that is problematic, and is initially displayed by the frown, relates to a breach in the progression of the conversation. In short, the frown and the subsequent turn mark a discontinuity in the current activity and bring out a problematic aspect in the topic of conversation that the co-interactant has not yet addressed, or has taken for granted.

Turn-opening frowns occur in what is referred to as the transition space (Schegloff, 1996), which is a local context "starting somewhere in a prior turn or TCU and lasting until somewhere in the next turn or TCU" (Schegloff, 1996: 96).

\footnotetext{
* Corresponding author. Tel.: +358 505865593.

E-mail addresses: timo.kaukomaa@helsinki.fi (T. Kaukomaa), anssi.perakyla@helsinki.fi (A. Peräkylä), johanna.ruusuvuori@uta.fi (J. Ruusuvuori).
} 
Transition spaces are therefore central places for the negotiation of 'what happens next' in a conversation. In addition, even though a transition space may include sections of the adjacent turns, this study focuses on the overt phases of these spaces - on the silent moment between two spoken utterances.

Between turns, certain communicative behaviour can occur, such as facial expressions, which anticipate the upcoming spoken turn. Schegloff refers to these as pre-beginning elements (Schegloff, 1996: 92-93), arguing that they project the onset of talk, but they are not yet properly recognizable turn beginnings, and they do not begin a TCU, which bears the actual contribution of the turn. Other pre-beginning elements apart from facial expressions include in-breaths, uh $(\mathrm{m})$ tokens, gestures, head movements, and gaze shifts (for more on pre-beginning elements, see e.g., Mondada, 2007; Streeck and Hartge, 1992).

The authors of this article recently reported (Kaukomaa et al., 2013) how another kind of turn-opening facial expression, smile, initiates a shift in emotional stance from one that is neutral or serious to one that is positive or humorous. We showed that turn-opening smiles are integrated parts of the turn (action) that they anticipate, initiating a new emotional stance already before the onset of talk. We also discovered that the recipients of these smiles regularly reciprocate them, as well as other emotional stance markers (such as laughter and lexical items) that the speaker expresses after the initial smile. In many cases, the recipients of the turn-opening smiles were the ones to escalate the introduced emotional stance, thereby not only reciprocating the new stance but also carrying it further. This paper reports on our continuing research on turn-opening facial expressions, examining in detail the interactional trajectories of turn-opening frowns.

When a person frowns, the eyebrows are brought together and pulled downward, and as a consequence vertical wrinkles appear on the person's forehead (see e.g., Ekman, 2007). Frowns and other facial expressions are linked to inner psychological and physiological states and processes, which in turn are related to the regulation of emotions. However, facial expressions are also used in social communication, serving various interpersonal functions. (Manstead et al., 1999; Niedenthal et al., 2006.) The main line of research examines facial expressions as spontaneous manifestations of human emotional processes (e.g., Ekman, 2007; Ekman and Friesen, 2003; Tomkins, 1963; Izard, 1997). From this perspective, frowns are understood to be linked to an individual's negative emotions, such as anger, disgust, or displeasure. Another, more recent line of research focuses on the social dimension of facial expressions: they are displayed for social purposes and they serve particular interpersonal and communication functions (e.g., Fridlund, 1997; Bavelas and Chovil, 1997, 2000; Chovil, 1997, 1991). Researchers focusing on frowns examine, for instance, how they (and other facial expressions) punctuate talk (Chovil, 1991), and also what information they contribute to the linguistic context of the conversation (e.g., Bavelas and Chovil, 1997, 2000). It is worth mentioning that Ekman $(1979,2004)$, who is usually considered the major proponent of the individual-centred view of facial expressions - argues that frowns also have their communicative functions in conveying uncertainty, perplexity, doubt and difficulty.

This paper follows the latter line of research, focusing on the interactional trajectories that are initiated by frowns in turnopening positions. Ruusuvuori and Peräkylä (2009: 381-382) reported recently that a frown displayed during the silence before talk may serve as a hint that the talk that is to come will involve some problematic aspects. The study reported here further examined how frowns that emerge before an utterance, and remain on the face when the speakers starts to talk contribute to the utterance as well as to the larger interactional and sequential context. In other words, our aim is to demonstrate how turn-opening frowns contribute to the construction of both meaning and action in conversation.

Another aspect of frowning that we analyze is the co-participants' responses to turn-opening frowns. We provide evidence that such responses are different from responses to turn-opening smiles. As we have previously reported, recipients regularly reciprocate the smiles that occur in the turn-opening position (Kaukomaa et al., 2013). In the process of analysing and discussing our data, we suggest that the interactional trajectories of turn-opening frowns and turnopening smiles differ substantially: most recipients did not reciprocate frowns. This observation is further supported by what has been reported previously in experimental studies: frowns seem not to be directly socially contagious (see e.g., Hinsz and Tomhave, 1991).

\section{Data and method}

Our data consist of five video-recorded dyadic Finnish conversations that were conducted over lunch. The participants were university students who knew each other. Three cameras were used, two of them recording the participants' facial expressions, and the third one covering the overall situation. The data contained 12 instances of turn-opening frowns. We included in our collection only frowns that emerged before the onset of an utterance and were maintained to the point of which talk was initiated. By virtue of their overlap with the spoken utterance, these frowns became part of the "gestalt of action" to which the talk also contributed (cf. Kaukomaa et al., 2013).

The data were transcribed and analyzed using conversation analytic (CA) methods. CA made it possible for us to examine the interpersonal communicative functions of turn-opening frowns in sequentially organized interaction (e.g., Stivers, 2013; Sacks et al., 1974). In practice, we looked at what happened in the conversations before the onset of the frowns and what happened next, ergo, how the recipients of the frowns responded to them (and to the utterances following them). Our aim in 
Table 1

Problem elements that the turn-opening frowns anticipated.

\begin{tabular}{lll}
\hline Negative evaluation & Disaffiliation & Epistemic difficulty \\
\hline $7 / 9$ & $6 / 9$ & $4 / 9$ \\
\hline
\end{tabular}

this analysis is to contribute to the recent studies that address the interplay between talk and bodily conduct (see e.g., Heath and Luff, 2013).

The turn-opening frowns were associated with something in the upcoming turn that was problematic. In most cases in our data (9 out of 12) the participants did not orient themselves in the preceding talk to something problematic. In the remaining three cases, however, the turn-opening frown continued a problem orientation that the co-interactant had initiated in her previous turn(s). Should be mentioned here that the interactional dynamics in these three cases were different from those in the main data set. The next section focuses on the majority of cases (9), which involve a turnopening frown that initiated an orientation to a problem that was not addressed in the preceding talk (see Table 1).

As Table 1 shows, a turn-opening frown typically anticipated a spoken turn containing elements of negative evaluation (in 7 out of 9 cases) and disaffiliation (in 6 out of 9 cases). One segment may involve more than one problem element. Thus, elements of epistemic difficulty were found with both negative evaluation (in 2 out of 9 cases) and disaffiliation (in 2 out of 9 cases). Two frown-initiated utterances involved elements of all three types of problem element. Epistemic difficulty was the only element that was found in isolation (without elements of the other problem types) in a spoken turn following a turn-opening frown (in 1 out of 9 cases): in that case the speaker was in the middle of a word search episode.

Next, we describe the conversational environments in which the turn-opening frowns occurred.

\section{The conversational context of turn-opening frowns}

The data show that utterances following turn-opening frowns occur in rather variable sequential environments: they may re-open an activity ${ }^{1}$ that has already been closed, disaffiliate from the preceding action, or give a pragmatically dispreferred second pair part or self-disclosure. In spite of the variation in the sequential location of turn-opening frowns, what they have in common is that they all anticipate an utterance that addresses something negative or problematic that has not been displayed in the previous turn(s). The subsequent utterances then disclose the negative content that the frowns foreshadow.

We now turn to the problems that the frowns anticipate. Inherent in the turns that follow them are three possible problematic elements. In all the occurrences in our data (9/9) the turn that followed a turn-opening frown contained elements of evaluation, and in seven of these cases the evaluation was negative. The turn also contained elements of disaffiliation in six out of nine cases, and elements of epistemic difficulty in another four.

We examine these elements in more detail in Section 4.

\section{The characteristics of problems that turn-opening frowns anticipate}

\subsection{Negative evaluation}

We begin our data analysis with an example of negative evaluation, which seemed to be the problem that was most commonly associated with a turn-opening frown (in 7 out of the 9 cases). Let us consider extract 1 .

Before the shown fragment, participant A was complaining about the local student healthcare centre, more specifically about her failed attempt to schedule a doctor's appointment in connection with a serious health matter. In a complaining tone she describes her interactions with the healthcare centre nurses, and anticipates the difficulties she might still face in trying to phone the centre at exactly the time when appointments are assigned. Just before the exchange represented in extract $1, B$, the recipient offers some advice in response to A's complaint, suggesting that A should phone the centre before the time when the appointments are scheduled, and explain to the staff that she really needs the appointment, and that she cannot phone at the official time.

In line 1, the recipient reaches the end of her advice, stating that she thinks the staff members should make an exception in A's case and grant her an appointment time at that moment. A agrees with this optimistic projection (cf. Jefferson, 1988) (line 2). Using this exchange, the participants establish an environment in which the closing of the topic and the action is

\footnotetext{
${ }^{1}$ The term activity here refers to culturally specific social activities that are interactionally recognized and accomplished. These activity sequences are constructed using various embodied resources in order to build particular social actions (that are constructed with multiple single turns), and typically comprise (social) actions by both participants through talk and the body (e.g., (storytelling) (cf. Drew \& Heritage, 1992; Levinson, 1992; also Stivers, 2013).
} 
relevant. B's response particle, $\mathrm{Mmm}$, in line 4, seems to function as a "sequence closing third" (Schegloff, 2007). A long silence follows (line 5). After six seconds, A frowns, before re-opening the topic and making a negative assessment (lines 5-6). It seems that at the moment A begins to frown, the participants are at the closure of a troubles telling phase, just after B has given A her advice, which A may not consider a proper response (cf. Jefferson and Lee, 1981; Jefferson, 1988).

\section{Extract 1}

1 B: $\quad$ Ni kyllä ne vois< (.) () (.) niinku poikkeevas tapaukses antaa sun (.) varat[a sen nyt.

2 A: So they could (.) () (.) like exceptionally let to you (.) make the a[ppointment now.

3

$4 \mathrm{~B}: \quad \mathrm{Mmm}$

(.)

[A begins to frown and to shake her head

$5 \mathrm{~A}: \quad(6.0)[(0.7)$

$6 \mathrm{~A}: \quad[$ Kauheen myö[hään<

[A stops shaking her head

7 B:

Awfully late<

$7 \mathrm{~B}: \quad$ [Siel on niin<

[There is so $<$

8

$9 \mathrm{~A}: \quad$ Siis $\mathrm{k}$ - et kauheen myöhään ne vaan tulee ne.

I mean a- it is awfully late that they'll come those.

$10 \mathrm{~B}: \quad$ Mmmm.

$11 \mathrm{~A}$ : $\quad$ Siis ne $(0.4)$ il- ilm- (.) tai et niitä voi varata.

$12 \mathrm{~B}: \quad \quad \quad \quad$ iii. Aina edellisen ku[un puolivälissä.

Yes. Always in the mi[ddle of the previous month.

After beginning to frown, A shakes her head before saying awfully late (lines 5-6). The negative assessment takes her back to her complaining action, pursuing an affiliative response from $B$. However, in the overlap with A's talk $B$, the recipient, initiates an assessment of her own, and due to their simultaneous talk, both participants stop talking. Next, A reformulates her complaining utterance (lines 9-11). In short, B produces a mm-token before A explicates the object of her negative stance (lines 10-11). We will now look more closely at how the turn-opening frown constituted part of A's negative assessment (Fig. 1).

During extract 1 , speaker A makes a negative assessment of the practices at the local student healthcare centre. Her verbal assessment is preceded by a frown and a head shake (Fig. 1, Pictures 1-2, lines 5-6). It seems that A's turnopening frown (with her head shake) was an integral part of her verbal negative assessment. In other words, the frown emerged after a lengthy silence, and remained on A's face throughout the beginning of her assessment until line 9 (see also Picture 3). Thus, the frown became an embodied part of the negative assessment "awfully late". The frown subsequently disappears from her face, giving way to an eyebrow flash after she starts to re-iterate her utterance (line 9). What is interesting here is that at the moment the frown disappears $B$, the recipient, has already turned her gaze towards $A$, and arguably, notices the frown (Picture 3). The frowning participant A, however, keeps her gaze down until B's acknowledgement token in line 10.

In sum, a frown emerged on A's face prior to her negative assessment of the spoken referent. This frown anticipated the negative assessment and became an embodied part of it. With this turn, A re-opened the topic and pursued an affiliation from the recipient, immediately after the recipient (B) had offered her advice (and A did not consider it a sufficient response to her troubles telling). A's negative assessment could also be seen as a minor disaffiliative move, as she was not satisfied with how the sequence closed or with how B had responded to her (cf. Jefferson and Lee, 1981; Jefferson, 1988).

Extract 2 below represents another case of a turn-opening frown conveying a negative assessment. Here the participants have been talking about eating fish, prompted by A's positive assessment of the smoked fish they are currently eating (not shown in the transcript). In the early moments of the extract, B wonders why she does not eat fish more often, even if it is very healthy, inexpensive and easy to prepare (lines 1-6). Through her utterance, B conveys a position that could be paraphrased as "fish is something very good and one should really eat more of it". The recipient, A, receives B's utterance using minimal acknowledgement tokens (lines 5 and 7 ). Through her responsive turn A concurs with B that like her, she does not eat much fish either. However, she gives many reasons for not eating fish (lines 9 and 11-12). A evaluates the spoken referent in negative terms. In fact she considers the consequences of eating fish rather repulsive. 


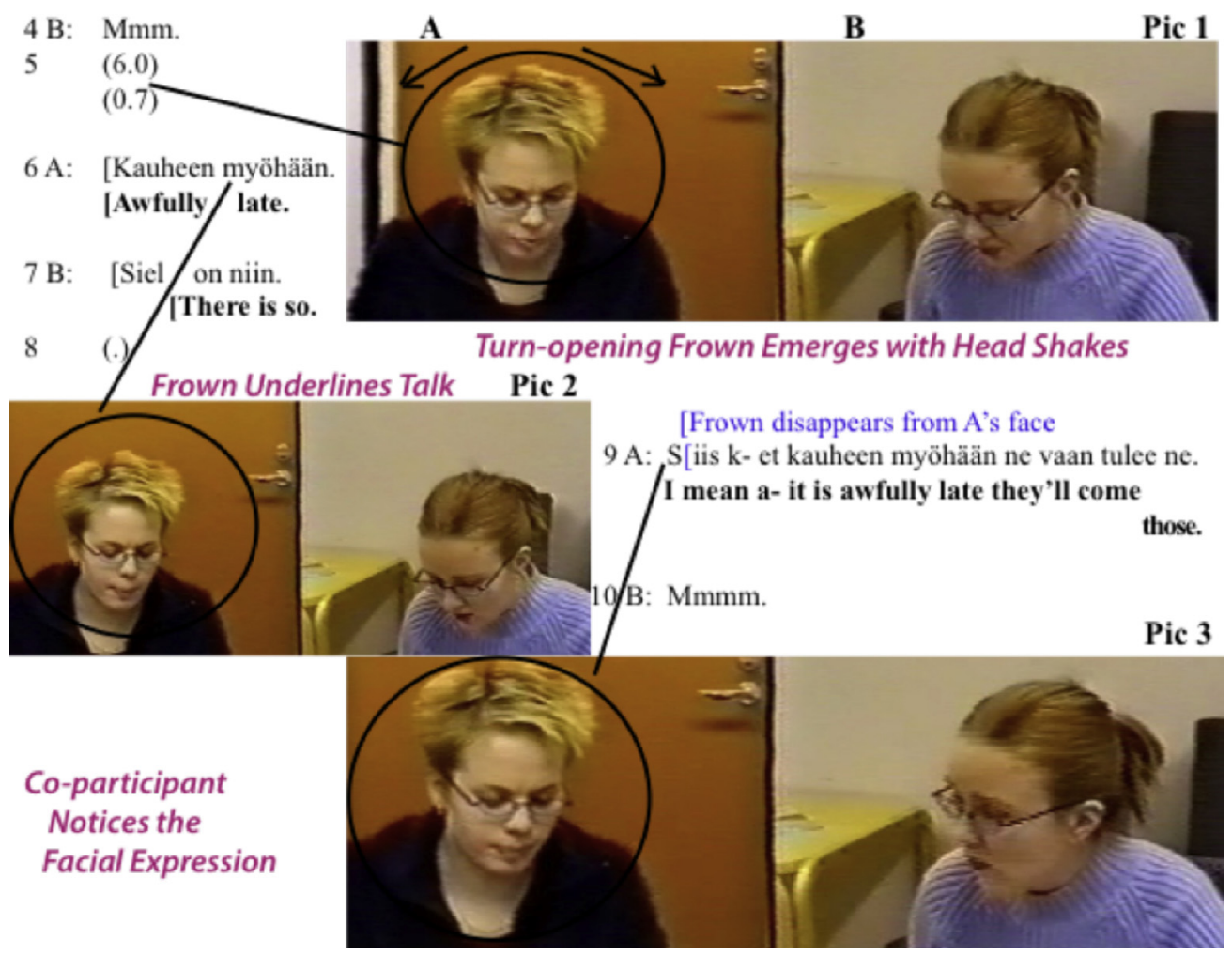

Fig. 1. A turn-opening frown preceding a negative assessment.

\section{Extract 2}

1

$2 \mathrm{~B}$ : 'ttä $\uparrow$ miks sitä ei tuu syötyy silleen kotonaki siis niinku paljon useemmin tai siis niinku so $\uparrow$ why I don't eat (fish) like at home like much more often or I mean like

3

5 A:

6 B: $\quad$ niin[ku [mitään, .hh

like[any, .hh

$7 \mathrm{~A}: \quad[\mathrm{Mmm} .((\mathrm{A}$ nods and smiles slightly))

[A begins to frown

$8 \quad(0.6)[(0.1)$

$9 \mathrm{~A}: \quad$ [\#Nii noh\# (0.3)] (0.1) mä en syö sen takia ku siitä aina jää ne

[\#Well yeah\# (0.3)] (0.1) I don't eat it because there's always the remains

$10 \mathrm{~B}: \quad$ [syytä tavallaan.]

[reason in a way.]

$11 \mathrm{~A}: \quad(0.3)$.mhhh ne tota (0.3) jämät ja kaikki nahkat ja kaikki

(0.3) .mhhh the erm (0.3) leftovers and the skin and all

12 ja sit ne haisee [sit koko kämppä haisee] and then they stink [then the whole apartment stinks

$13 \mathrm{~B}:$

$[\uparrow$ Nii joo ei £ku tästähä m]e puhuttiinki tästä haju [joo£.
[ $\uparrow$ Oh yes £we already talked about this bad smell [yeah£.

14 A:

((B smiles while talking))

ja .sn[ff ei se nyt nii kallistakaa ois e[es eikä siis ees vaikeeta laittaa että ei

and .sn[ff it wouldn't ev[en be that expensive or difficult to cook so there's not

[mhe 
$16 \mathrm{~B}$ : Niin puhuttii[nki muute kerran.

$17 \mathrm{~A}:$

Yes we really talk[ed about it once.

$[\mathrm{Mm}$,

A closer examination of extract 2 shows that $A$ frowns just before beginning her evaluative turn giving her reasons for not eating fish (lines 8-9).
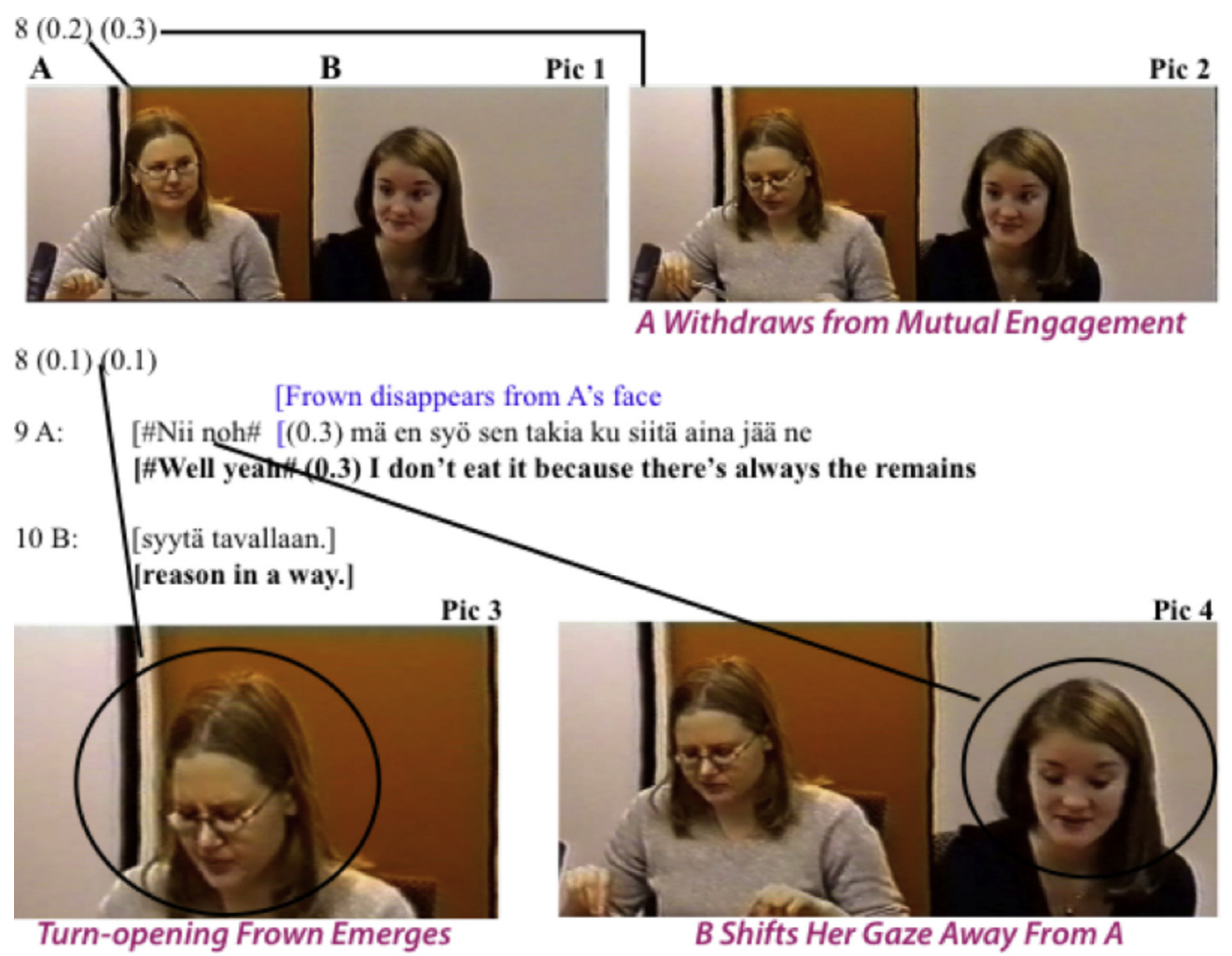

Fig. 2. A turn-opening frown preceding a negative evaluation.

$B$ turns to $A$ in line 6 , immediately after making made her point understood to her. A, who is already looking at $B$, nods and smiles slightly in response (see Picture 1 in Fig. 2). With her nod and smile, in combination with her minimal response tokens (lines 5 and 7), A seems to convey her acknowledgement of B's self-deprecating comments about not eating enough fish. However, A falls short of full agreement. During the silence that ensues (line 8), A turns her gaze away from B (Picture 2), who still continues gazing at her. A frown subsequently appears on A's face (Picture 3). Immediately after she has begun to frown, A says Nii noh (an approximate translation is well, yeah) in a creaky voice (line 9). The frown, combined with the dispreference-implicative turn-initial particles, creates an impression that something negative or problematic is about to occur. Overlapping the start of with A's turn B completes (line 10) her previous, unfinished utterance (the earlier part of this utterance occurs in lines 2-4,6). Simultaneously with her talk, she withdraws her gaze from $A$ (Picture 4). It is evident from the timing of her gaze and its withdrawal that before shifting her gaze away from her $B$ had noticed A's turn-opening frown.

A pause occurs after A's turn-initial particles (line 9), during which the turn-opening frown disappears from her face. After the silence, A launches into an evaluative account of the reasons why she does not eat fish. First, she states, I don't eat it because there's the remains (line 9) in a complaining or uneasy tone. A pauses for a moment before changing her tone of voice, adopting a slight smile as she begins to explain in a lively manner the reasons why she dislikes eating fish (lines 11-12). This involves a negative evaluation of the "consequences", which is nevertheless softened by the humorous tone of A's utterance.

In sum, the turn-opening frown emerged when a responsive turn (in agreement) on eating fish was made relevant. The frown started an utterance that created disagreement with between the participants, even though it also gave a vague 
impression of reflecting that they were both on the same side because neither of them ate fish regularly. The speaker (A) continued to frown during the beginning of the utterance and, as a consequence, conveyed a negative evaluation of the spoken object. As the frown was displayed under the recipient's gaze and occurred with the talk, it was produced as an integrated part of the stance that was conveyed in the turn.

Extracts 1 and 2 represent cases of turn-opening frowns that foreshadow a negative evaluation that is conveyed in the following utterance. The preceding contexts in both these cases were delicate or troublesome, and the utterances that began with frowns comprised an evaluation that was somehow unexpected and difficult with regard to the co-participant's previous turn. These turns also contained elements of disaffiliation, which we now consider in more depth with reference to another problem that is foreshadowed by turn-opening frowns.

\subsection{Disaffiliation}

In extract 2 above, the negative evaluation conveyed by the utterance that follows the turn-opening frown also implies disaffiliation between the participants. As mentioned earlier, the turn-opening frown emerged when an affiliative response would normally occur (such as yes, we should all eat more fish), after the frowning speaker had engaged in actions that conveyed less than full agreement with her partner (the acknowledgement token, nod and smile in line 7). However, that situation became more complicated because the latter speaker's turn contained self-deprecating elements that the coparticipant was not supposed to endorse (Pomerantz, 1984). Moreover, immediately after she begins to frown, A says Nii noh/well yeah in a creaky voice (line 9). The turn-opening frown, alongside the dispreference-implicative turn-initial particles, gave the impression that a disagreement was being formulated. Furthermore, the utterance that followed the turn-opening frown (lines 9 and 11-12) gives the grounds for the disagreement. The position that $A$ assumes here is partly aligned and partly misaligned with the position B had exhibited in her previous utterance. Indeed, A agrees with B as someone who does not eat fish but unlike $B$ she thinks there are very good reasons for her choice. Whereas $B$ points out the benefits of fish in terms of health, cost and the straightforward preparation, $A$ introduces the disagreeable consequences of preparing meals containing fish. B seems to be alert to the problem of disaffiliation, as is evident in lines 12-13 when she emphasizes prosodically (see especially the delivery of the turn-initial particles Nii joo/Oh yes) that now she recalls A's difficulty. At this moment in their conversation, B initiates a move towards restoring affiliation.

In the case of extract 2, the disaffiliation that was foreshadowed by the turn-opening frown was intertwined with the negative evaluation of the spoken referent. Extract 3 below shows that a turn-opening frown may also foreshadow mere disaffiliation without including a component of negative evaluation. The interlocutors had agreed to go jogging later that evening (not shown in the transcript). At the time of the recording, it was winter when some of the tracks might be in poor shape. The participants discuss the state of the tracks. Although they both describe the conditions as good for running, they nevertheless disaffiliate from each other's assessments. B's turn-opening frown (line 6) seems to show an awareness of this rather complex disaffiliation.

$B$ remarks in line 1 that luckily the weather is rather good at the moment, and that conditions are not wet and slushy. Next, in lines 3 and 4, A suggests that the tracks along which they might be jogging have probably been gritted.

\section{Extract 3}

1 B: $\quad$ Nyt on ihan hyvä ilmaki silleen et ei oo mitään (0.3) märkää ja loskasta.

$2 \quad(2.4)$

$3 \mathrm{~A}$ : $\quad$ Kai noi on tuolt hiekotettu noi $(0.5)$ jotkut Seppälän

$4 \quad \begin{aligned} & \text { Perhaps they have gritted (0.5) som } \\ & \text { reititki että sinne pääse[e (aika hyvin). }\end{aligned}$

$5 \mathrm{~B}$ : tracks at Seppälä so that you'l

$6 \quad(0.2)[(0.1)$

((B shakes head from side to side while talking))

$7 \mathrm{~B}$ : $\quad$ Mm (.) ei siel oo (mun mielestä) liukast [ollu nytte, no there have my mind-toslipperybeennow

8 A:

9

$10 \mathrm{~A}$ :

Mm (.) (I don't think) it's slippery [out there now,

(1.3) ((A nods twice))

$[\mathrm{Mmm}$.

$$
\text { No }
$$

Well 
(2.0) ((points and shakes her finger, chews and swallows food))

$12 \mathrm{~A}$ : Sit seki ois tänä iltana (0.8) tuolla $(0.3) \mathrm{mts}($.$) onks se nyt Johanneksen kirkossa$

Then again tonight (0.8) there's that $(0.3) \mathrm{mts}($.$) is it now in St. John's$

kirkossa oli se (0.3) Picasso-kuoro ja (.) joku,

Church there was that (0.3) Picasso choir and (.) someone,

$B$ is eating bread during A's utterance in lines 3 and 4 . She shifts her gaze to $A$ and makes a mm-sound just as $A$ is about to finish her utterance (lines 4-5). This seems to acknowledge A's hedged (see turn-initial perhaps) statement regarding the condition of the tracks. However, during the ensuing silence B withdraws her gaze from A and simultaneously frowns, thereafter offering another 'no problem' evaluation of the conditions (lines 6-7, Pictures 1-3 in Fig. 3). Subtle disaffiliation between the participants emerges. By referring to the gritting of the tracks in her utterance in lines 3-4, A presupposes that there could be ice on them, thereby slightly disaffiliating from B's initial positive assessment of the weather and the tracks in lines 1-2. The disaffiliation/disagreement is more evident in B's turn in line 7, which begins with a turn-opening frown (line 6): through its marked word order (turn initial eilno; see the grammatical gloss in line 7) and the inclusion of a perspective component (mun mieleställ think) the utterance is designed to disagree with what $A$ has just conveyed.

$B$ begins her utterance in line 7 by producing a mm again to acknowledge A's turn, and then continues by saying ei siel oo (mun mielestä) liukast ollu nytte/(I don't think) it's slippery out there now (line 7). B uses her turn to disagree with a key presupposition of A's preceding evaluation, which on the other hand is somewhat misaligned with B's previous positive evaluation regarding the condition of the tracks (line 1). However, A's reflection on whether or the tracks would be gritted is somewhat in alignment with B's first evaluation. (During the winter in Finland, when the temperature drops after wet and slushy weather conditions on the roads tend to become icy and slippery.) A says that the tracks will probably be gritted so they could go jogging but as far B is concerned the condition of the tracks is not an issue because they are not icy or slippery in any case.

B's turn-opening frown that foreshadowed the countering evaluation remains on her face (accompanied by a few lateral head shakes) well into her evaluative turn, giving way to her raising her eyebrows after she has conveyed her point (at the word ollu/been). Just before her frown disappears she shifts her gaze back to A. Participant A, who is the recipient,

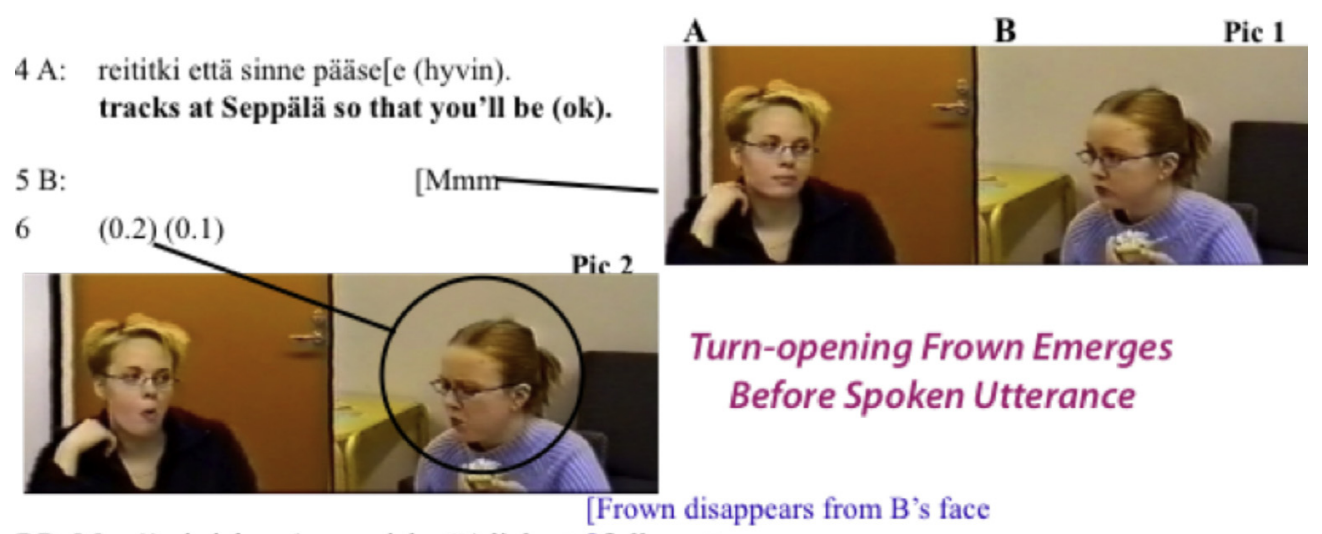

7 B: Mm (.) \& siel oo (mun mielestä) liukasta[ [ollu nytte,

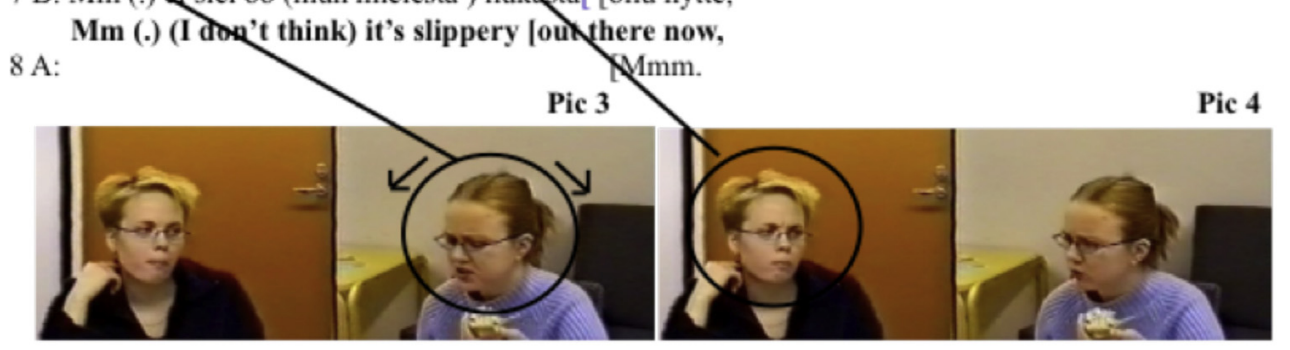

B Shakes Head While Talking

Frown Penetrates Utterance

Recipient Mimics Facial Expression

Fig. 3. A turn-opening frown preceding a disaffiliative utterance. 
maintains her gaze at B throughout B's turn in line 7. What is exceptional in this case is that A reciprocates B's turnopening frown during B's expression mun mielest/in my opinion, just before she shifts her gaze to $A$. Consequently, just for a moment both participants are frowning. As soon as $B$ turns her gaze back on $A$, her frown gives way to the raising of eyebrows. At this point however, $A$, the recipient, continues frowning even after the completion of B's utterance, making a few nodding gestures at the same time. B, in turn, reciprocates these nods. It appears that in reciprocating B's turnopening frown, $A$ is indicating that she has recognized the (problematic) aspects of her previous evaluation concerning the condition of the tracks (lines 3-4) with which B disagreed. However, she does not correct that evaluation: her frown and nods give the impression that, after B's second 'no-problem' evaluation, she is ready to move on and to drop the issue (and it remains unresolved). Indeed, in line 10, A initiates a new topic concerning another possible activity for the evening.

The turn-opening frown in extract 3 foreshadowed an evaluative utterance that involved disaffiliation from the previous speaker's position. The problem that caused the frown was not the evaluation per se, in other words the assumption that the tracks were not slippery but was rather attributable to the complex form of the disagreement. The frowning speaker B had problems with the presupposition (about the condition of the tracks) inherent in A's evaluation, which she challenged in the turn that began with a turn-opening frown.

Extract 4 is another example of a turn-opening frown foreshadowing disaffiliation.

Participant $B$, who recently met an interesting man in a pub, was told by her friend that he was not 25 as he said, but could be as old as 29. At the beginning of this extract $B$ reflects on the fact that, although there is a possibility that the man lied about his age, she does not think he did (lines 1-9). The recipient, A, who was also in the pub at the time and had also met the man in question, has difficulty agreeing with $B$ on this issue.

\section{Extract 4}

$1 \mathrm{~B}: \quad$ Jaa no $(0.8)$ oishan se nyt periaattees voinu tietyst valehdella.

$2 \quad \begin{array}{ll}\text { Oh well } \\ 3\end{array} \quad(0.4)$

$3 \mathrm{~A}: \quad \mathrm{Mm}[\mathrm{m}$.

4 B: $\quad[. m h h h$ ikänsä $>$ mut< $\quad(0.3)$ mun mielest se ei kyl näyttäny kakskytyheksänvuotiaalta.

$5 \quad(1.0)$

$6 \mathrm{~A}: \quad \mathrm{Mmm}$.

$7 \quad(0.3)$

$8 \mathrm{~B}$ : $\quad$ Eikä niinku (2.3) ku se niinku ihan loogisesti kerto $£(h)$ niitä elämänsä vaiheita nii

Nor like (2.3) when he like talked logically $£(h)$ about those phases of his life so

$9 \quad £$ Esiihen ei niinku mahu £n(h)i[i montaa vuotta oikeesti sillee£. .mhhhh

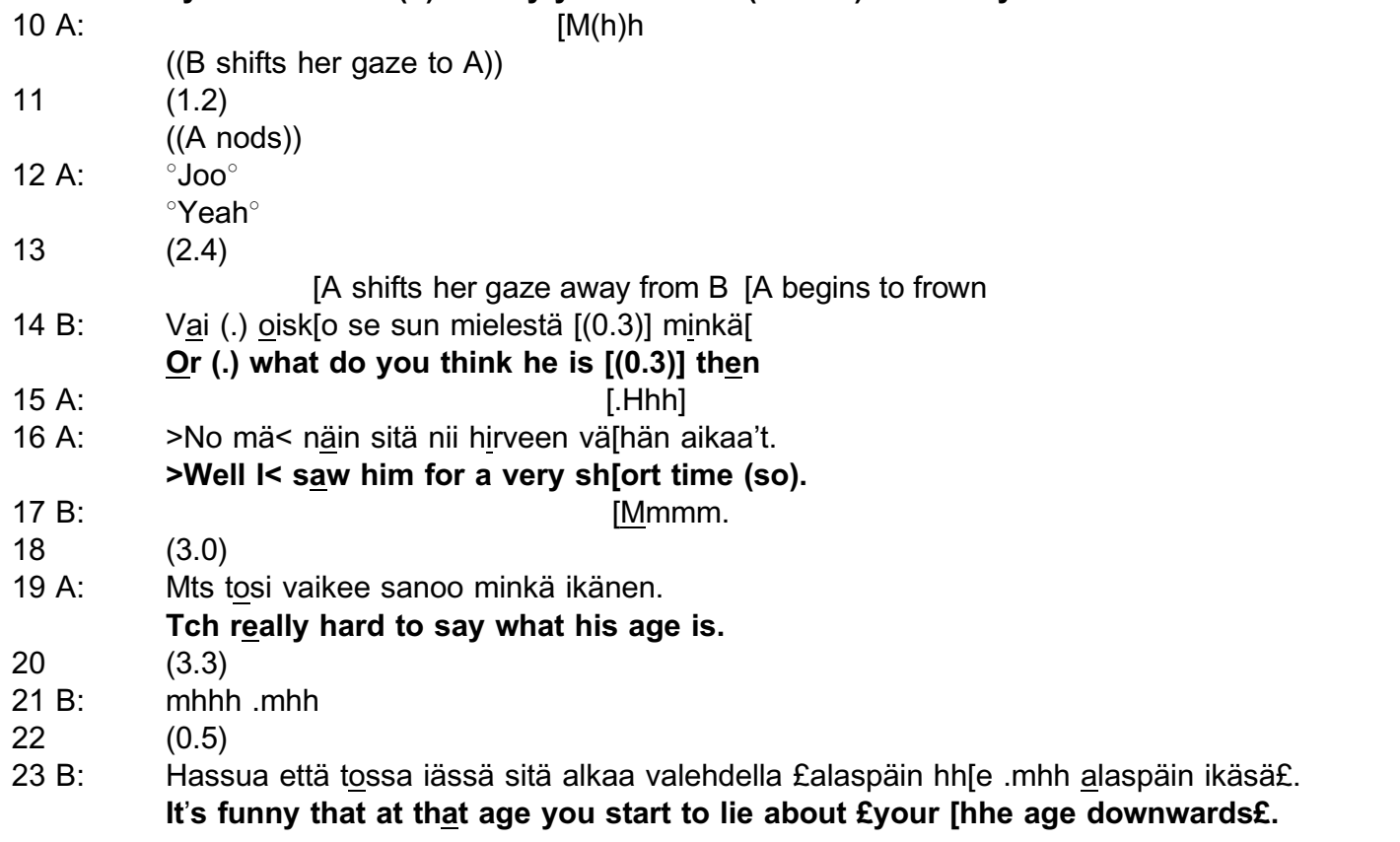
£you can't fit $£ s(h) o$ many years in that (his life) like really£. .mhhhh 
$24 \mathrm{~A}:$

25

26 A:
(0.2)

[mhe he

After stating in line 1 that there might be a "theoretical" chance that the man lied about his age (but implying that she does not believe he did), B allows space for A to come in and offer her opinion (line 2). A only produces a minimal acknowledgement token however (line 3 ), whereas B points out the reasons supporting her belief that the man did not lie about his age (line 4). A silence follows this second evaluative utterance, and one second later $A$, the recipient, produces another neutral response token (line 6). Next, in lines $8-9, B$ again explains why she thinks the man is, in fact, as young as he had claimed to be. B smiles during her turn. In response, A also smiles and produces a laugh particle (line 10). Other than this, however, she remains silent (lines 10-11). B briefly shifts her gaze to $A$, apparently in an attempt to elicit a response from her (cf. Stivers and Rossano, 2010) (line 11). Next, in response, A says yeah in a low voice and nods, which could be interpreted as an attempt to close the sequence (line 12). After two and half seconds of silence, B finally formulates an explicit question, asking vai oisko se sun mielestälor what do you think he is then (line 14). This question increases the pressure on A to response (Stivers and Rossano, 2010), and seems to be a result of B's failure to elicit any substantial response from $A$ with regard to her assessments. As $B$ is asking her question, $A$ withdraws her gaze from her, breathes in and frowns before producing her answer (Pictures 1-3 in Fig. 4, lines 14-16).

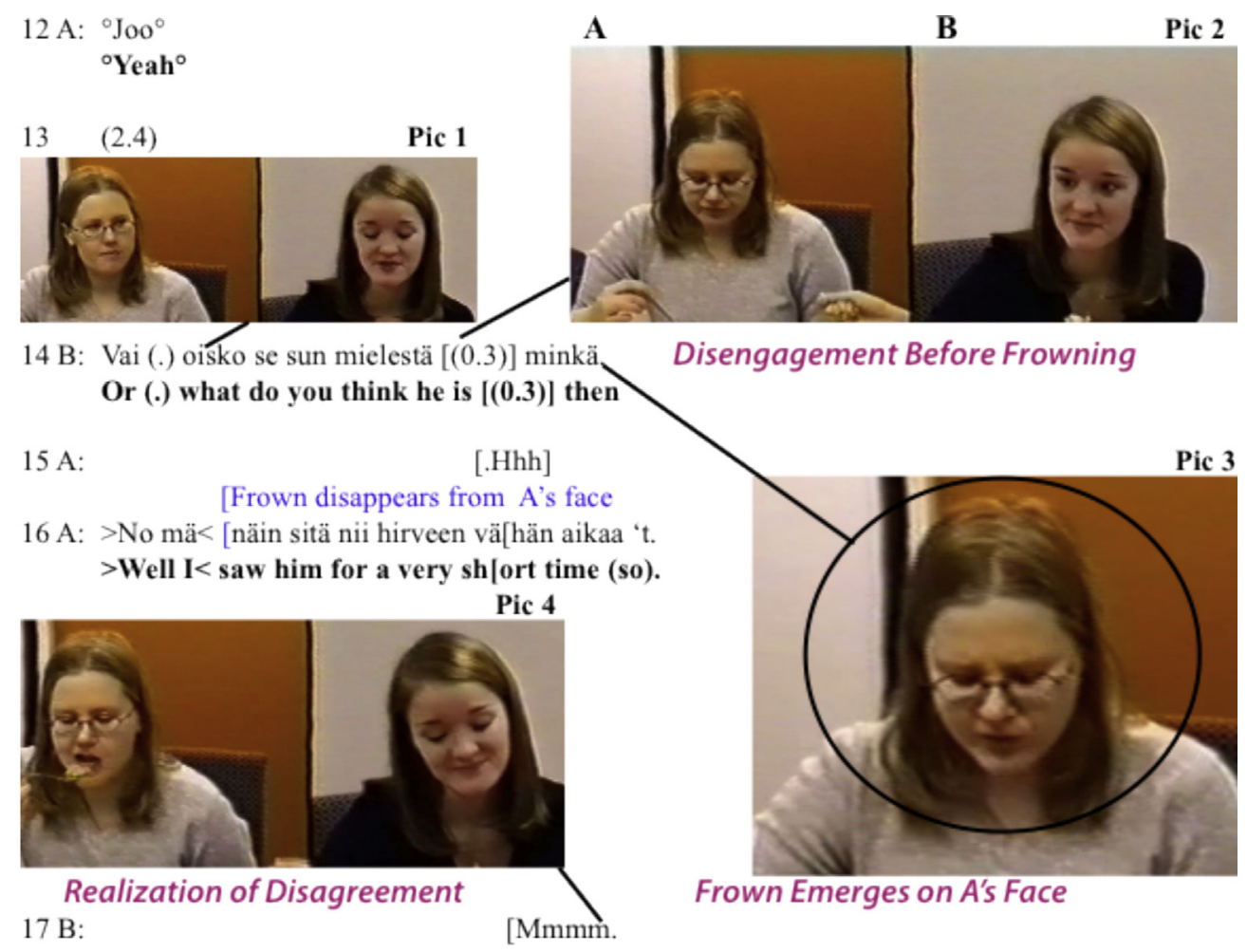

Fig. 4. A turn-opening frown preceding a multifaceted problem display.

The turn-opening frown remains on A's face over the onset of the upcoming turn, disappearing after the word mä (I) in line 16. A states that it is difficult to estimate the man's age because she had seen him for such a short time (lines 16-19). Throughout this account $A$ again declines to offer a second assessment, in other words she neither agrees nor disagrees with B.

B seems to interpret A's claimed inability to answer as implying disagreement, as B withdraws her gaze from A (Picture 4 in Fig. 4, line 17) and changes her position regarding the man's age during her utterance in line 23 (now presupposing that the man is older than he claimed to be). As A instantly ratifies B's words and her new (lighter) stance (conveyed with a smile and laughter, lines 23-24) through a mm-sound and a nod (line 26), A makes it clear that she can agree with this more humorous interpretation that the man is an older person who lies about his age. As a consequence, their mutual affiliation seems to be re-established. 
The turn-opening frowns in extracts 2-4 foreshadowed disaffiliative utterances. We will now move on to consider the third problem associated with turn-opening frowns, epistemic difficulty.

\subsection{Epistemic difficulty}

With reference to extract 4, which we examined above, A's account in lines 16 and 19, which was foreshadowed by a turn-opening frown, refers to the following display of an epistemic challenge: Well I saw him for such a very short time. (...) really hard to say what his age is. Thus the spoken action (evaluation) that the turn-opening frown anticipates involves not only disaffiliation, but also a display of epistemic difficulty. The frown does not differentiate between the two: it seems to project a gestalt of action that involves both.

Extract 5 below contains another example of a turn-opening frown that foreshadows an epistemic difficulty, which as in extract 4 above, is integrated with disaffiliation. $B$ has just initiated a new topic and action, complaining about a caretaker who clears the snow from the yard of the apartment building in which she lives (lines 1-2). As it later transpires (not shown in the transcript), the snow clearance is noisy and the caretaker does it very early in the morning. In line 2 , however, $B$ halts the progression of her utterance, and using a parenthetical utterance, asks A whether a small tractor (apparently a similarly noisy machine as the one the caretaker in her building uses) is also used to clear the snow in A's block (lines 4-5). This question involves a word search (see line 4); B appears to have difficulties in categorizing the small 'thing', and settles for 'tractor'. Towards the end of B's questioning (see line 5), A withdraws her gaze from B and looks down. During the silence that follows, A frowns before starting to answer B's question (lines 6-7, Pictures 1-3 in Fig. 5).

\section{Extract 5}

$1 \mathrm{~B}$ : $\quad$ Meillä on se (0.8) pirun huoltomies ni .hhh just ku se niitä $(0.7)$

$2 \quad$ We have this $(0.8)$ damn caretaker

roa- yard there (0.4) with tha[t.mh

3 A:

$[\mathrm{Mm}$

4 B: $\quad$ >Siis< $\quad(0.3)$ kä:yks teillä siellä pihalla semmosella pienellä

em $\uparrow$ mää tiiä mikä

$>I$ mean< $(0.3)$ does someone come into your yard with a small I $d \uparrow$ on't know what

[A gazes down

$5 \quad$ joku semmonen pikkutraktori hel[vetti millä. .mhh

(kind of) something like a small tractor oh to hell with. .mhh

$6 \quad(0.1)[(0.1)$

$7 \mathrm{~A}$ : Mts. E- Emmä tiä kyl se musta aika [isolta näyttää se. I-don't know indeed it to-me rather big looks it

$8 \mathrm{~B}:$

9

[Mmhh

$10 \mathrm{~B}: \quad \quad \quad \quad \quad[i$ jaa mh no meill] on semmonen pieni .hh ja siis viime talvenaha se alotti aina siinä

$\mathrm{O}[\mathrm{h}$ well $\mathrm{mh}$ we] have that like a small .hh and like last winter it always started then

After she starts to frown, A states emmä tiä kyl se musta aika isolta näyttää se/l don't know well I think it looks rather big (line 7), referring to the size of the tractor. A's turn-opening frown then gradually fades from her face, so that by the word isoltalbig, her facial expression is neutral once again. (Because the Finnish word order here is different from the English translation, we give a word-by-word translation of line 7, inserted between the original Finnish and the idiomatic English lines.) With her utterance A displays her uncertainty or difficulty in assessing the size of the tractor that is used to clear the snow in her yard.

A's utterance in line 7 focuses on the size of the tractor that clears the snow and involves complex and subtle disaffiliation with B's preceding utterance (the question about the small tractor in line 4-5). B's question seeks a yes-or-no answer (whether or not a small tractor is also used in A's block), probably preferring a yes answer. Rather than answering unambiguously 'yes' (or 'no') however, A states that the tractor used in her block seems rather big. Thus she does not explicitly deal in her turn with what $B$ focused on in her question - whether or not she is disturbed in the mornings by a tractor clearing. At best, she implies partial confirmation (a tractor is used in her block, too), and questions the relevance of a key descriptor in A's question (the smallness of the tractor). 
$4 \mathrm{~B}: \quad>$ Siis< $<(0.3)$ kä:yks teillä siellä pihalla semmosella pienellä em $\uparrow$ mää tiiä mikä $>\mathrm{I}$ mean< $(0.3)$ do:es someone come into your yard with a small $\mathrm{I} d \uparrow$ ' $’$ 't know what

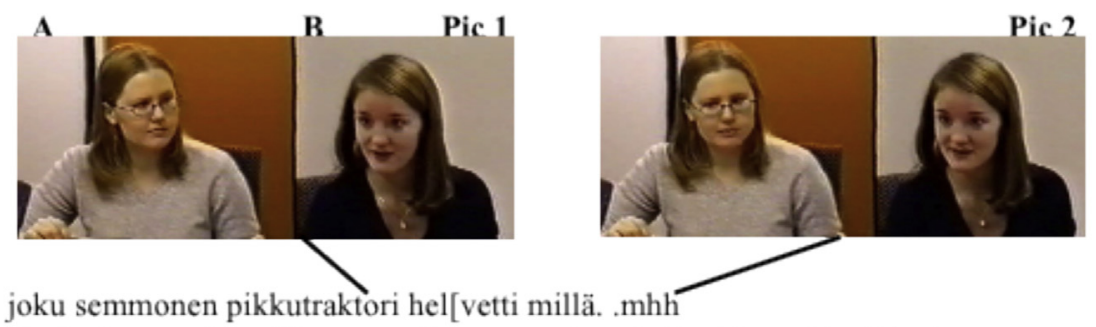

5

(kind of) something like a small tractor oh to hell with. .mhh Pic 3

6

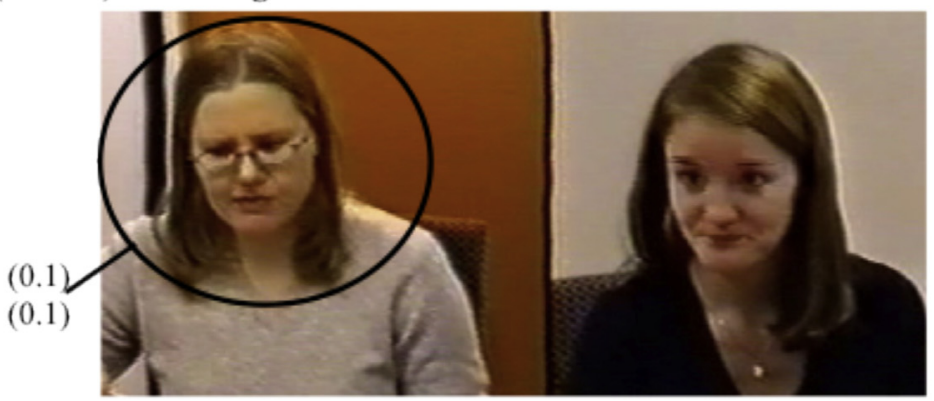

Frown Emerges

on A's Face

[Frown disappears from A's face

7 A: Mts. Emmä tiä kyl se musta [aika [isolta näyttää se.

Mts. I don't know well I think it looks rather big.

$8 \mathrm{~B}$ :

[Mmhh.

Fig. 5. Turn-opening frown preceding a display of epistemic uncertainty.

Thus, as in extracts 2-4 discussed above, the utterance (in extract 5) anticipated by the frown involves disaffiliation. With its long preface, A's answer indeed exhibits some of the classical features of a dispreferred response (cf. Pomerantz, 1984). However, here as in extract 4 , an epistemic difficulty is involved. Whereas the questioner (B) had difficulties with the category 'tractor', the respondent (A) had trouble finding a category to characterize the size of the machine. Her hesitation (I don't know well I think it looks. . .) reflects this difficulty. The shape of the frown on her face seems to incorporate the epistemic aspect of the problem: upon close examination, her face in Picture 3, Fig. 5, seems to convey "pondering" rather than displeasure or worry. In maintaining this pondering expression she does not lower her brows as much as they could be lowered, and she fixes her gaze in the middle distance, straight ahead (cf. Heath, 1986), which means that she is gazing neither up nor down.

\section{Summary of the findings}

We have shown in this paper how the interlocutors in our data frowned in anticipation of utterances involving interactional problems. Such problems were associated with negative evaluation, disaffiliation and epistemic difficulty. We have demonstrated how turn-opening frowns persist into the utterances that they anticipate, and as a result become integrated into what is being said. The utterance or utterances that follow(s) the turn-opening frown expose(s) the grounds for the problem.

The problem that these turn-opening frowns anticipate typically arises from the sequential context. There is a misfit between the turns that start with frowns and what has been going on just before. A turn-opening frown typically initiates a turn containing elements of negative evaluation (7/9) and disaffiliation (6/9). Displays of both negative evaluation and disaffiliation deal with the problem that the frown foreshadows. In cases of negative evaluation (see extracts 1-2) the speaker draws connections between her more or less personal 'problem' and the spoken referent. The problem source lies in the negative characteristics of a spoken object with which the speaker is currently dealing, or has experienced in the past (extracts 1-2), and which is then displayed or re-enacted in situ. It seems that when the evaluation is not negative, the source of the problem is not in the past event or the negative characteristics of a spoken object but in the previous turn(s) of the co-interactant, or in the difficulty of assessing or describing the object. 
Our data include only two cases of a turn-opening frown initiating an evaluative turn without any negative evaluation, as shown in extracts 3 and 5 . The problem in the former was related to the co-participant's previous turn (correcting the cointeractant's turn, and consequently disaffiliating from her), whereas in extract 5 it was related to assessing and categorizing the spoken referent, in other words to epistemic difficulty. What was apparently common in all the turns beginning with a turn-opening frown was that they carried "a problem of the speaker" that would create a breach in the progression of the current activity. Moreover, the turn-opening frown seems to signify that the upcoming turn will not perfectly fulfil the expectations aroused by the previous turn, and thus will temporally halt the smooth progression of the activity.

The participant (and upcoming speaker) who exhibits a turn-opening frown typically gazes downwards and away from the recipient. In many cases (e.g., extracts $2-5$ ), the frowning participants withdraw their gaze from their co-participant shortly before the onset of the frowning. In other words, the gaze withdrawal and the frown onset can therefore be perceived as part of the same continuum of gestures. Moreover, turn-opening frowns are typically made under the recipient's gaze, or if the recipient looks away the speaker continues to frown until the recipient shifts her gaze and perceives the frown. However, having seen the turn-opening frown, and having heard what it was about, the recipient typically does not reciprocate the facial expression. In this sense the trajectories of turn-opening frowns are markedly different from those of turn-opening smiles that we examined recently (Kaukomaa et al., 2013). In short, smiles are typically reciprocated whereas frowns are not. Our data on turn-opening frowns that initiate a new problem orientation contain only one instance when the recipient reciprocates the frown, which we presented in extract 3.

The fact that the frowning participant typically looks down before and during the process seems to contribute to the non-reciprocation of the frown. Gazing at the co-participant when beginning to frown, or directing one's gaze at her soon after frowning could constitute an invitation to share the expression (and the stance) (cf. Kaukomaa et al., 2013), which is not what the frowning participants in our data typically do. Interestingly, in the only case in which the frown is reciprocated (see extract 3 ) the gaze behaviour of the initially frowning participant is different in that she looks at the recipient while frowning.

Even though turn-opening frowns are typically produced when the speakers shift their gaze down, and are not reciprocated by their recipients, they still constitute a communicative practice. In that the recipients typically look at the frowning participants at some point (this was the case in all the extracts presented here). Thus, the recipients clearly notice the frowns. It is also possible that frowning participants are able to observe the recipient gaze through their peripheral vision. It would seem, then, that there is something paradoxical in the sociability of turn-opening frowns: although they are not offered for the recipient to share, they nonetheless occur under her gaze. Frowns of this type therefore constitute solitary actions that occur in the presence of another speaker. It may be that they give the co-participant a clue that the speaker is encountering some problem and is about to embark on a dispreferred turn.

Although a turn-opening frown typically begins a turn that has disaffiliative elements in it, in our data there are disaffiliative utterances that do not involve turn-opening frowns. By briefly considering the difference between disaffiliating turns with and without turn-opening frowns, might enhance understanding of their purpose. One key characteristic of disaffiliative turns initiated with a frown is that the disaffiliation tends to be complex, or even ambiguous. Thus, in extract 1 , the frowning speaker had just affiliated with the co-participant and collaborated in the closing of the topic, but then frowns, re-opens the topic and disagrees. In extract 2, the frowning speaker affiliates with the co-participant in not eating fish, but disaffiliates from her in having good reasons for her choice. In extract 3 , the frowning participant in fact agrees about the condition of the tracks (they are good for running) but questions the co-participant's grounds for her opinion, whereas in extract 4 , she claims to be unable to assess the referent when asked to do so by her co-participant. Finally in extract 5 , the frowning participant in effect gives a 'yes' answer, but disagrees with characterization of the referent (small tractor). In comparison, dissaffilitive utterances expressed without frowning are often more straightforward. In many of these instances the speaker openly addresses something potentially problematic associated with the co-interactant's previous turn. The speaker may point out something the co-interactant has forgotten to mention, or express her own countering opinion on the spoken referent. Moreover, while openly displaying disaffiliation, the speaker in such cases may also convey a humorous stance (e.g. smiles, laughs or talks in the smiley voice). This may happen when she challenges the co-interactant's viewpoint, for instance. In such cases of open disaffiliation we have found no turn-opening frowns.

Another difference between disaffiliative turns with and without turn-opening frowns concerns the role of the speaker. It seems that when such turns begin with a frown the speaker typically foregrounds herself as a personal actor, as in extracts 2-5. In all of them the speaker refers to, or highlights, herself as an actor by prefacing her assessments or assertions with self-referential components: in extract 2, mä en syö sen takia ku/l don't eat it because, in extract 3, mun mielestä/l think, in extract 4, mä näin/l saw, and in extract 5, emmä tiä/l don't know. Thus, it seems that in these cases the speaker is using the turn design to foreground herself as an actor, which may be related to the fact that she is producing a turn that contradicts or is misaligned with her co-interactant's previous turn. Interestingly, in extract 1, where the speaker uses the impersonal form, she has problems not in sharing her co-interactant's opinion or viewpoint but in the way she is responding to her troubles-telling. In contrast, speakers making disaffiliative utterances without frowning tend to do so without foregrounding or highlighting their own actorship. 


\section{Discussion}

Schegloff (1996: 92-93) suggested that incipient facial expressions, such as frown, belong to the category of prebeginning elements, "which project the onset of talk, or the beginning of a (next) TCU or a turn, but are not yet recognizable turn beginnings". According to Schegloff, pre-beginning elements are not part of the turn construction unit that contains the actual contribution of the turn. This study has shown how turn-opening frowns function as pre-beginning elements and how they may contribute to the spoken turn they anticipate.

As we have demonstrated, the turn-opening frowns stayed on the speakers' faces until after the talk beginning and thus became integral to the turn's action. In this sense they did not merely project a turn beginning, they were part of it. Although pre-verbal in the unfolding trajectory of a turn, turn-opening frowns form a constitutive part of the action that is being carried out (cf. Kaukomaa et al., 2013 on turn-opening smiles). Such pre-verbal practices could also be analyzed as initial contextualizing segments of a TCU, without which the recipients would not be able to interpret the action properly (cf. Lindström, 2006, 2008). In this sense, it could be argued that turn-opening facial expressions work in a way that is comparable to the working of discourse particles, which are also used to contextualize and position, and typically precede the verbal core contribution expressed in a TCU.

The turn-opening frowns in our data anticipated a problem display, and the utterances that followed specified the problem. Furthermore, our evidence indicates that these problem displays contain elements of negative evaluation, disaffiliation and/or epistemic difficulty.

Problem elements involve complications that arise in the expected course of events during interaction. The frowns seemed to foreshadow the utterances that somehow deviated from routine expectations. They also occurred in sequential contexts in which a sequence that has already been closed is re-opened, or when affiliative next moves would be expected. Turn-opening frowns thus seem to indicate that the speaker is about to do something that will involve a slight breach of what would be expected at that precise moment based on the previous turn. This frowning while gazing away from the co-participant seems to embody the 'private' cognitive processing of this breach within the subject, and simultaneously - by virtue of being produced under the other's gaze - probably serves as an interactional device that prepares the recipient to cope with a momentary breach.

It seems that turn-opening frowns mark the following utterance as something that the speaker is contemplating, as if he or she were fully considering the matter at hand. This is also observable in the shape and location of the turn. In addition, these frowns are intertwined with the utterances that they foreshadow, which are made independently of the preceding turn, although they deal with the same issue or topic. However, we should emphasize the fact that our results are based on a small amount of data, and future research on frowns in turn opening as well as in other positions would shed us further light on their interactional and sequential functions.

Erving Goffman $(1981,129-130)$ argues that visual cues are vitally important for both the speaker and the hearer in face-to-face encounters, and makes the following observation:

In the management of turn-taking, in the assessment of reception through visual back-channel cues, in the paralinguistic function of gesticulation, in the synchrony of gaze shift, in the provision of evidence of attention (as in the middle-distance look), in the assessment of engrossment through evidence of side-involvements and facial expression-in all of these ways it is apparent that sight is crucial, both for the speaker and for the hearer. For the effective conduct of talk, speaker and hearer had best be in a position to watch each other. ${ }^{2}$

Goffman further argues that in the assessment of engrossment, visual "side-involvements" - facial and gestural cues are crucial "for the effective conduct of talk". With respect to our study, the frowns and shifts in the participants' gazes (both the speakers and the recipients) play a central role in the collaborative management of the activity in which they are engaged. Therefore, the emerging and ending points of a turn-opening frown, as well as the speaker's (and also the recipient's) gaze behaviour constitute significant parts of the action (they convey important information) that is under construction, and directly affect how the recipient will recognize and respond to it.

However, we should point out that the recipients did not show much awareness of the frowns as such, but their overt next action was targeted to the talk they anticipated (except in extract 3, where the recipient mirrored the frown). Thus, it seems that recipients orient to the whole gestalt of the turn that carries the action, which was initiated by a turn-opening frown that was an integral part of it.

It appears that in displaying their private cognitive processing via turn-opening frowns, speakers help their cointeractants to recognize an impending problem that is to be addressed. Hinting at this problem beforehand by means of pauses, gaze shifts, head turns and other embodied markers of dispreference, speakers also use frowns before turns of

\footnotetext{
${ }^{2}$ Italics in the original text.
} 
talk to indicate that they are encountering a difficulty that needs be addressed in order to determine the missing shared line of action and then return to smoothly flowing conversation. Finally, it seems that displaying one's inner, private cognitive state works as an interactional tool or resource to preserve intersubjectivity during problematic conversational moments (on systemic inter-relations between the internal and interactional regulation of cognitive-emotional states, see Beebe and Lachman, 2002).

\section{Acknowledgements}

We are deeply indebted to Jörg Bergmann, Pentti Henttonen, Mikko Kahri, Jan Lindström, Mika Simonen, Melisa Stevanovic, Liisa Voutilainen, Elina Weiste and two anonymous reviewers for their insightful and helpful comments on an earlier version of this paper. The research was funded by Academy of Finland (project 1132303) and the Finnish Centre of Excellence in Research on Intersubjectivity in Interaction.

\section{Appendix A}

1. Transcription notation:

[ ] or overlapping talk

[or] marks the place of a particular embodied action

(0.5) length of silence in tenths of a second

(.) micro-pause

. falling intonation

? rising intonation

, continuing intonation, slightly rising

level intonation

h exhalation

.h inhalation; inbreath

\# \# creaky voice

$<$ talk is markedly slow or drawn out

$><$ talk is compressed or rushed

$\uparrow \quad$ intonation rises

$\infty$ portions quieter than the surrounding talk

$=$ contiguous utterances (no break or gap)

- cut-off

: $\quad$ prolongation of immediately preceding sound

- (underline) emphasis

(( )) transcriber's descriptions

( ) unheard word

$£ £$ word(s) uttered with a smile in the voice

\section{References}

Bavelas, Janet, Chovil, Nicole, 1997. Faces in dialogue. In: Russell, J.A., Fernandez-Dols, J.-M. (Eds.), The Psychology of Facial Expression. Cambridge University Press, Cambridge, pp. 334-346.

Bavelas, Janet, Chovil, Nicole, 2000. Visible acts of meaning. An integrated message model of language in face-to-face dialogue. Journal of Language and Social Psychology 19 (2), 163-194.

Beebe, B., Lachman, F.M., 2002. Infant Research and Adult Treatment: Co-constructing Interactions. Analytic Press, Hillsdale, NJ.

Chovil, Nicole, 1991. Discourse-oriented facial displays in conversation. Research on Language and Social Interaction 25, $163-194$.

Chovil, Nicole, 1997. Facing others: a social communicative perspective on facial displays. In: Russell, J.A., Fernandez-Dols, J.-M. (Eds.), The Psychology of Facial Expression. Cambridge University Press, Cambridge, pp. 321-333.

Drew, Paul, Heritage, John, 1992. Analyzing talk at work: an introduction. In: Drew, P., Heritage, J. (Eds.), Talk at Work: Interaction in Institutional Settings. Cambridge University Press, Cambridge, pp. 3-65.

Ekman, Paul, 1979. About brows: emotional and conversational signals. In: von Cranach, M., Foppa, K., Lepenies, W., Ploog, D. (Eds.), Human Ethology. Cambridge University Press, Cambridge, pp. 169-248.

Ekman, Paul, 2004. Emotional and conversational nonverbal signals. In: Larrazabal, J.M., Perez Miranda, L.A. (Eds.), Language, Knowledge, and Representation. Kluwer Academic Publishers, The Netherlands, pp. 39-50.

Ekman, Paul, 2007. Emotions Revealed. Henry Holt, New York.

Ekman, Paul, Friesen, Wally, 2003. Unmasking the Face: A Guide to Recognizing Emotions From Facial Expressions. Malor Books, Cambridge, MA. 
Fridlund, Alan J., 1997. The new ethology of human facial expressions. In: Russell, J.A., Fernandez-Dols, J.-M. (Eds.), The Psychology of Facial Expression. Cambridge University Press, Cambridge, pp. 103-129.

Goffman, Erving, 1981. Footing. In: Goffman, Erving (Ed.), Forms of Talk. University of Pennsylvania Press, Philadelphia, pp. 124-157.

Heath, Christian, 1986. Body Movement and Speech in Medical Interaction. Cambridge University Press, Cambridge.

Heath, Christian, Luff, Paul, 2013. Embodied action and organizational activity. In: Sidnell Jack, Stivers Tanya, (Eds.), The Handbook of Conversation Analysis. Wiley-Blackwell, Oxford, pp. 283-307.

Hinsz, V.B., Tomhave, J.A., 1991. Smile and (Half) the world smiles with you, frown and you frown alone. Personality and Social Psychology Bulletin 17, 586-592.

Izard, Carroll E., 1997. Emotions and facial expressions: a perspective from Differential Emotions Theory. In: Russell, J.A., Fernandez-Dols, J.-M. (Eds.), The Psychology of Facial Expression. Cambridge University Press, Cambridge, pp. 57-77.

Jefferson, G., 1988. On the sequential organization of troubles talk in ordinary conversation. Social Problems 35, 418-441.

Jefferson, G., Lee, J.R.E., 1981. The rejection of advice: managing the problematic convergence of a "TroublesTelling" and a "Service Encounter". Journal of Pragmatics 5, 399-422.

Kaukomaa, Timo, Peräkylä, Anssi, Ruusuvuori, Johanna, 2013. Turn-opening smiles: facial expression constructing emotional transition in conversation. Journal of Pragmatics 55, 21-42.

Levinson, Stephen C., 1992. Activity types and language. In: Drew, P., Heritage, J. (Eds.), Talk at Work: Interaction in Institutional Settings. Cambridge University Press, Cambridge, pp. 66-100.

Lindström, Jan, 2006. Grammar in the service of interaction: exploring turn organization in Swedish. Research on Language and Social Interaction 39 (1), 81-117.

Lindström, Jan, 2008. Tur och ordning. Introduktion till svensk samtalsgrammatik. Norstedts, Stockholm.

Manstead, Anthony S.R., Fischer, Agneta H., Esther, B.J., 1999. The social and emotional functions of facial displays. In: Philippot, P., Feldman, R.S., Coats, E.J. (Eds.), The Social Context of Nonverbal Behavior. Cambridge University Press, Cambridge, pp. $287-313$.

Mondada, L., (2007). Multimodal resources for turn-taking: pointing and the emergence of possible next speakers. Discourse Studies, 9:2, pp. 195-226. [Reprinted in Dijk, T. van (Ed.). Discourse Studies, London: Sage, vol. IV, pp. 126-157].

Niedenthal, Paula, Krauth-Gruber, Silvia, Ric, Francois, 2006. Psychology of Emotion: Interpersonal, Experiential, and Cognitive Approaches. Psychology Press, New York.

Pomerantz, Anita, 1984. Pursuing a response. In: Atkinson, J.M., Heritage, J. (Eds.), Structures of Social Action. Cambridge University Press, Cambridge, UK, pp. 152-163.

Ruusuvuori, Johanna, Peräkylä, Anssi, 2009. Facial expressions and spoken utterances in assessing stories and topics. Research on Language and \& Social interaction 42 (4), 377-394.

Sacks, H., Schegloff, E.A., Jefferson, G., 1974. A simplest systematics for the organization of turn-taking for conversation. Language 50, $696-735$.

Schegloff, E.A., 1996. Turn organization: one intersection of grammar and interaction. In: Ochs, E., Schegloff, E.A., Thompson, S.A. (Eds.), Interaction and Grammar. Cambridge University Press, Cambridge, pp. 52-133.

Schegloff, E.A., 2007. Sequence Organization in Interaction. A Primer in Conversation Analysis, vol. 1. Cambridge University Press, Cambridge.

Stivers, Tanya, 2013. Sequence organization. In: Sidnell Jack, Stivers Tanya, (Eds.), The Handbook of Conversation Analysis. Wiley-Blackwell, Oxford, pp. 191-209.

Stivers, Tanya, Rossano, Frederico, 2010. Mobilizing response. Research on Language and Social Interaction 43, 3-31.

Streeck, J., Hartge, U., 1992. Gestures at the transition place. In: Auer, P., di Luzio, A. (Eds.), The Contextualization of Language. John Benjamins, Amsterdam, pp. 135-157.

Tomkins, Silvan, 1963. Affect Imagery Consciousness: The Negative Effects (Vol. 1). Springer, New York.

Timo Kaukomaa is a doctoral candidate at the Department of Social Research at the University of Helsinki, and a member of the Finnish Centre of Excellence on Research on Intersubjectivity in Interaction. His doctoral dissertation deals with facial expressions and emotions in mundane interactions.

Anssi Peräkylä is Professor of Sociology at the University of Helsinki and the vice director of the Finnish Centre of Excellence on Research on Intersubjectivity in Interaction. His research interests include emotion in interaction, psychotherapy, and conversation analysis. He has recently co-edited "Conversation Analysis and Psychotherapy" (Cambridge University Press 2008) and "Emotion in Interaction" (Oxford University Press 2012).

Johanna Ruusuvuori is Professor of Social Psychology at the University of Tampere. Her research interests include professional-client interaction in health care encounters (general practice, homoeopathy, maternity health care, psychotherapy), interaction in multiprofessional meetings, emotion in social interaction, intertwine of facial expression and spoken interaction, qualitative methodology and conversation analysis. She has published in journals such as Social Psychology Quarterly, Social Science \& Medicine, and Journal of Pragmatics. In her current research, she develops evaluation methods for occupational health promotion. 